\title{
STRUCTURE AND PROPERTIES OF GLOW DISCHARGE IN ARGON WITH HOLLOW CATHODE
}

\author{
V.A. Lisovskiy, R.O. Osmayev, D.I. Khilko, V.D. Yegorenkov \\ V.N. Karazin Kharkiv National University, Kharkiv, Ukraine \\ E-mail: lisovskiy@yahoo.com
}

This paper deals with studying into the modes of burning and structure of the glow discharge with a hollow cathode and a flat anode in argon. We have demonstrated that the electron beam usually leaving the cathode cavity in a high voltage (glow mode) disappears when the anode approaches the edge of the hollow cathode. In this case the discharge is burning only on the outer surface of the cathode plates forming the cavity. The anode motion does not affect essentially the properties of the discharge burning in the hollow mode. We have obtained the axial intensity profiles of the emission lines of argon atoms and ions in the hollow and glow modes for various gas pressure and discharge current values. We have also shown that the brightest lines correspond to the transitions from $3 p^{5} 4 p$ to $3 \mathrm{p}^{5} 4 \mathrm{~s}$ levels. The lines corresponding to the transitions from higher levels as well as the emission lines of argon ions possess a rather low intensity.

PACS: 52.80.Hc

\section{INTRODUCTION}

Glow discharge with a hollow cathode is widely applied in Hall type thrusters (ion plasma engines) [1 - 3], in spectrum sources in atom-absorption spectroscopy, for pumping gas-discharge lasers etc [4 - 6]. The discharge with a hollow cathode may be employed as a plasma source for the production of wide ion beams of gases because it is stable and uniform [7].

Discharges with a hollow cathode permit to perform efficient extraction of the laser emission out of the chamber limits [6]. An option of creating a large, longitudinally extended plasma of negative glow as well as the application of cathode sputtering as a source of metal atoms make the discharges with a hollow cathode an active medium for the excitation of the laser transition of non-volatile metals such as $\mathrm{Cu}, \mathrm{Au}, \mathrm{Ag}$ etc [8]. The so called ion lasers employing metal vapors produce the required concentration of metal atoms conventionally by cathode sputtering, and the inversion of laser levels is accomplished via charge exchange collisions with $\mathrm{He}$, Ne or Ar ions.

Optimal application of glow discharge requires the knowledge of its properties in different modes of burning $[8-20]$. We have studied how varying the distance between the flat anode and the hollow cathode affects the modes of burning and the structure of the glow discharge in argon, as well as constructed the axial intensity profiles of emission lines of argon atoms and ions under various conditions.

\section{EXPERIMENTAL}

In order to study the discharge with a hollow cathode we have employed the chamber with the design shown in Fig. 1. The glass tube had the inner diameter of $56 \mathrm{~mm}$. As a hollow cathode we have employed two metal plates $2 \mathrm{~mm}$ thick each, distanced $8 \mathrm{~mm}$ apart and fixed on a flat disc $55 \mathrm{~mm}$ in diameter. The length of these plates was $37 \mathrm{~mm}$. The movable anode might be located at the distance $1 \ldots 375 \mathrm{~mm}$ from the edges of the hollow cathode plates.

The gas supply system puffed argon into the discharge chamber. The capacitive manometer (MKS Baratron) was used for pressure measurements with the maximum measured value of 10 Torr. The experiments have been performed in the argon pressure range of $0.1 \ldots 1$ Torr.

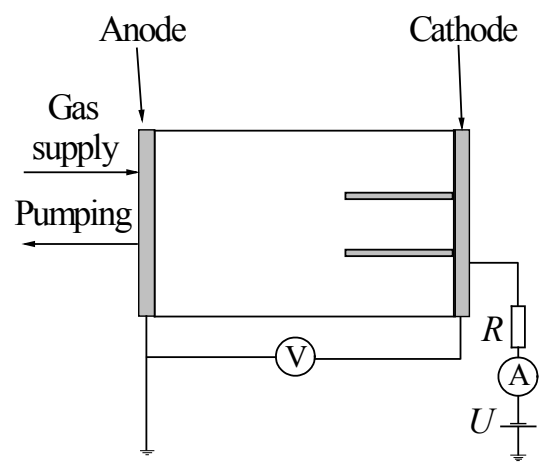

Fig. 1. The scheme of the experimental setup

We have employed the optical spectrometer Qmini (RGB Lasersysteme) to measure the axial profiles of emission lines of argon atoms and ions in the wavelength range of $300 \ldots 1000 \mathrm{~nm}$.

\section{EXPERIMENTAL RESULTS}

As was said above, we have moved the flat anode with respect to the edges of the hollow cathode and observed the modes of burning that are established and a structure the discharge has. Fig. 2 shows the discharge photos for different inter-electrode distance values. The figure demonstrates that no glow is observed in the cathode cavity at the minimum distance of $1 \mathrm{~mm}$. The discharge is outside the cathode cavity, and it consists of cathode sheaths (pressed to the outside surface of cathode plates and the surface of the flat disc to which they are fixed) and the negative glow (limited by the cathode sheaths, tube walls and the surface of the flat anode). Now let us move the anode off the edge of the hollow cathode. With the distance between them exceeding $5 \mathrm{~mm}$, we observe the glow at the cathode cavity exit corresponding to the electron beam associated with the high-voltage mode. A portion of positive ions, entering the cathode sheath from the negative glow near the edges of the cathode plates, hits the cathode surface inside the cavity. The secondary electrons produced by the ion-electron emission are focused by the electric field of the cavity and they form the electron beam directed along the discharge axis to the anode (a more detailed 
picture of the electron beam production is described in papers $[12,21,22])$. But when the anode is located too close to the cathode, the probability for ions to get into the cavity is small, therefore the electron beam is not observed. When the anode moves further away, the negative glow envelops all the cathode surface (outside its cavity). Then, when the anode is located in the medium portion of the dark Faraday space, a thin film of anode glow appears near its surface [23 - 30]. With the still further anode departure a positive column is built up with a stratification at low pressure (it consists of a sequence of bright and dark layers within which production and loss of charged particles dominate, respectively [31 - 36]).
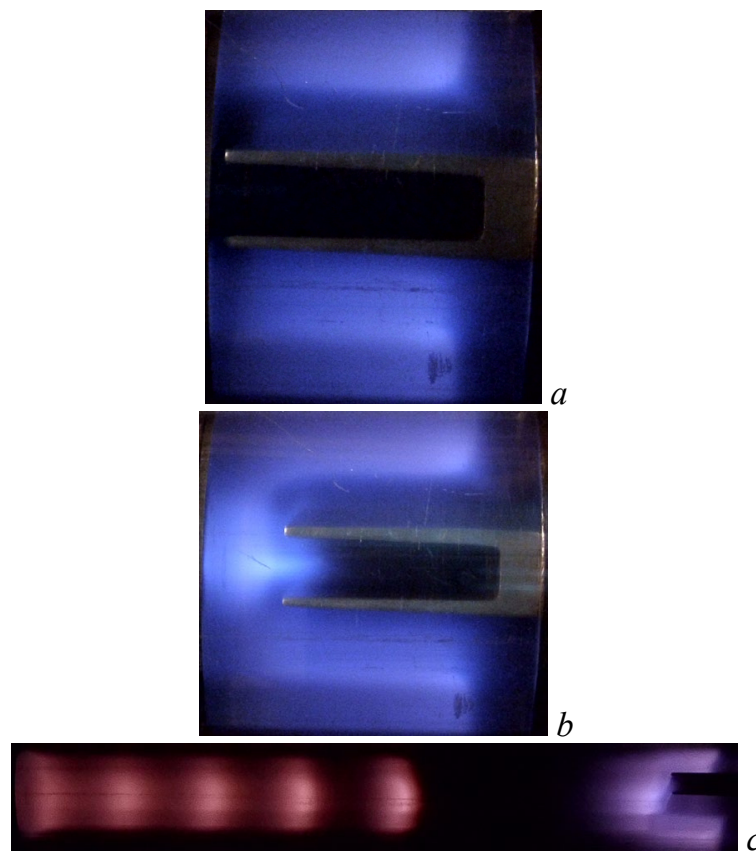

Fig. 2. Photos of the discharge in high-voltage mode (with an electron beam) at the argon pressure of

0.1 Torr, the current of $5 \mathrm{~mA}$ and the distance between the hollow cathode edge and a flat anode: a) $1 \mathrm{~mm}$; b) $12 \mathrm{~mm}$; c) $342 \mathrm{~mm}$

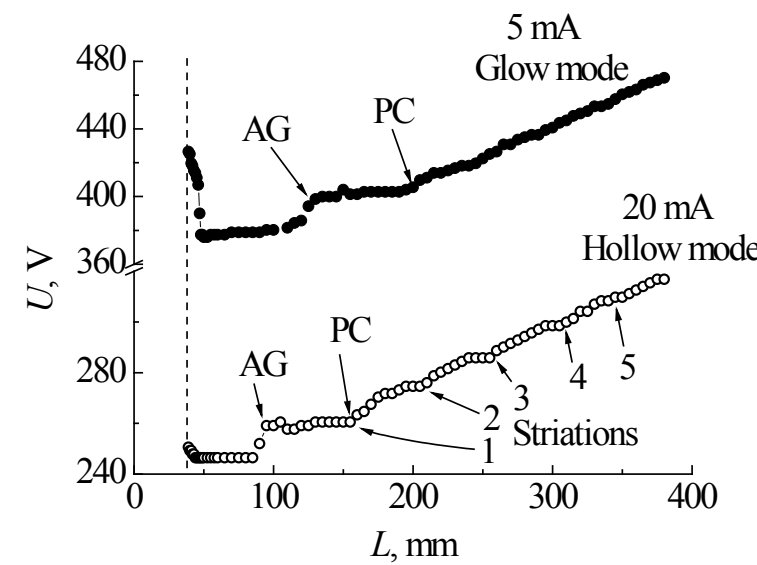

Fig. 3. Voltage across the electrodes against the distance between the flat portion of the hollow cathode and the anode at the argon pressure of 0.1 Torr and the discharge current values of $5 \mathrm{~mA}$ (glow mode) and $20 \mathrm{~mA}$ (hollow mode). The vertical broken line indicates the location of the hollow cathode edge
Note that we have kept a fixed value of discharge current while displacing the anode. Therefore the voltage across the electrodes experienced changes depending on the region of the discharge where the anode was located. In Fig. 3 we have presented the dependence of the current on the distance between the flat anode and a hollow cathode under the conditions corresponding to Fig. 2. At small distances, when the anode spans the considerable portion of the cathode sheath, the discharge is burning in the obstructed mode, when high voltage values are required to support it [23, 24, 30]. One usually observes the voltage across the electrodes increasing when the anode is moving away from the cathode through the negative glow while operating the discharge with flat electrodes [23]. However for a hollow cathode the voltage remains almost constant as the considerable portion of the negative glow is located near the outer surface of cathode plates and it is not in contact with the anode. In Fig. 3 the lettering AG and PC denote the distance values at which the anode glow appears near the anode and then the positive column forms. One observes in Fig. 2,c that the positive column consists of four complete strata and a bright portion of the fifth stratum. One can observe small jumps of potential which accelerate electrons to the energies sufficient for gas ionization on the linear portion of the curve in Fig. 2,c corresponding to the positive column. These jumps may be observed more clearly on the curve for the $20 \mathrm{~mA}$ current (see Fig. 3), where the positive column consists of 5 complete strata (see Fig. 4).

With the current of $20 \mathrm{~mA}$ (Fig. 4) the discharge fills the cathode cavity, and the hollow mode is observed. At the shortest distance of $1 \mathrm{~mm}$ the discharge is located only inside the cathode cavity actually not leaving its limits. However, on moving the anode from the cathode edge the negative glow is extended also to the outside of the cavity, but its intensity is considerably lower than that inside the cavity. Similar to the case of low current, the anode glow and the positive column appear when the anode is located sufficiently far from the cathode. But with high current the positive column forms at a lesser distance between the anode and the cathode. With flat electrodes the positive column appears at such a distance from the cathodes at which fast electrons accelerated in the strong electric field of the cathode sheath lose their energy and they are not capable to support a sufficiently large ionization rate and to carry a remarkable portion of the discharge current [31 - 36].

Then a positive column is necessary because in it the electric field strength is sufficiently high for the ionization production that may compensate all electron losses (due to ambipolar escape to the tube walls, to the drift to the anode, and in the case of an electro-negative gas to electron attachment to its molecules) [37]. In the case of a hollow cathode a considerable portion of fast electrons is contained inside the cavity oscillating in it (so called "pendulum effect"), and only a small quantity of them moves away from the cathode in the anode direction. Therefore the edge of the positive column is observed at a lesser distance from the cathode in which the cavity is filled with negative glow compared to the discharge in the high-voltage mode (without plasma filling the cavity). 


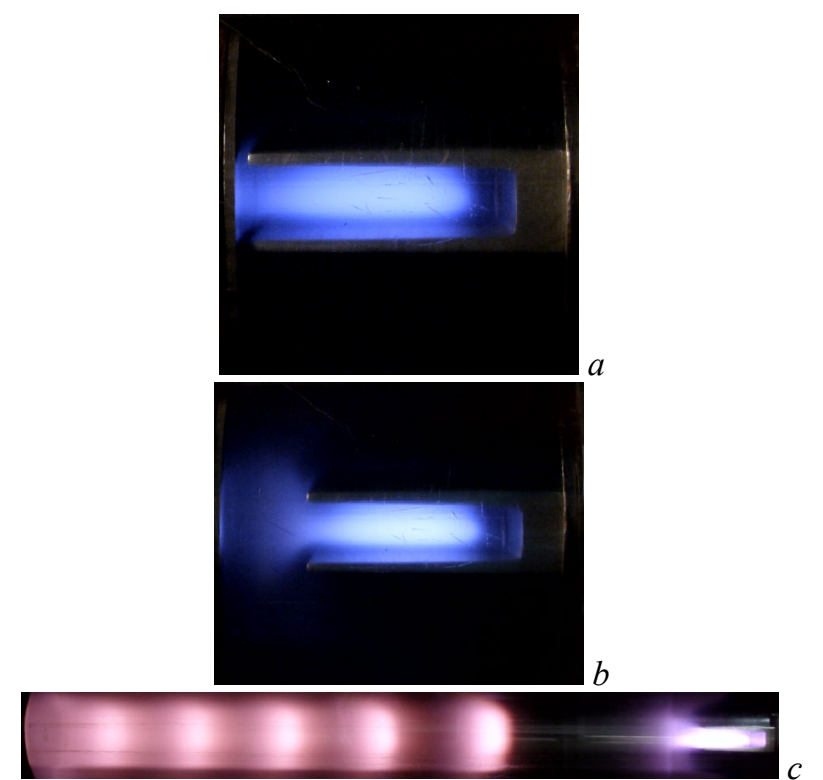

Fig. 4. Photos of the discharge in hollow mode at the argon pressure of 0.1 Torr, the current of $20 \mathrm{~mA}$ and the distance between the hollow cathode edge and a flat anode: a) $1 \mathrm{~mm}$; b) $12 \mathrm{~mm}$; c) $342 \mathrm{~mm}$
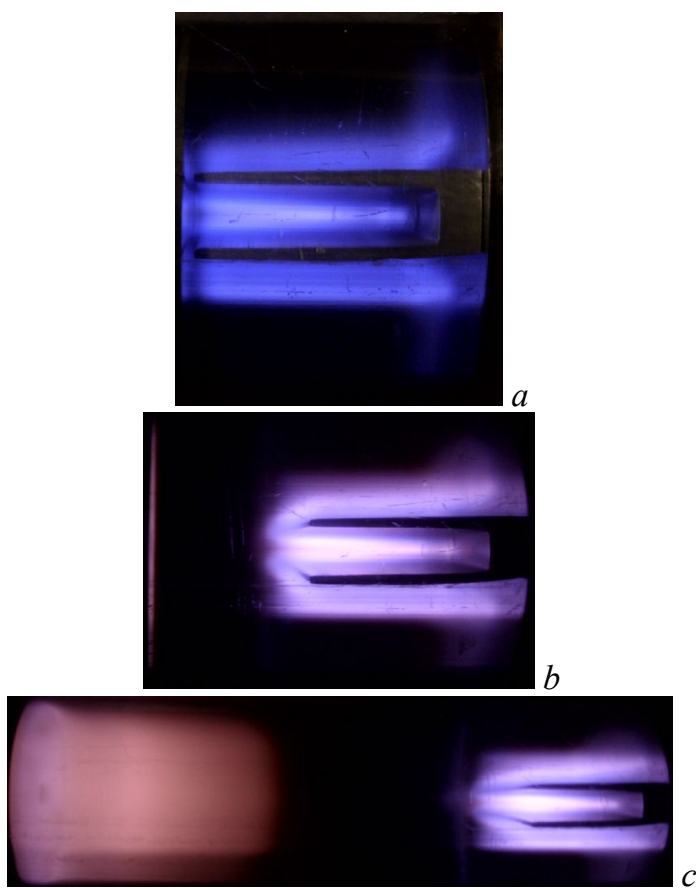

Fig. 5. Photos of the discharge in hollow mode at the argon pressure of 1 Torr, the current of $10 \mathrm{~mA}$ and the distance between the hollow cathode edge and a flat anode: a) $1 \mathrm{~mm}$; b) $27 \mathrm{~mm}$; c) $132 \mathrm{~mm}$

At high argon pressure (see e.g. the case of 1 Torr in Fig. 5) the cathode sheath thickness is small amounting about to $2 \ldots 3 \mathrm{~mm}$. The negative glow actually envelops the cathode surface tightly from inside the cavity as well as from outside it (of course, when the discharge already experienced a transition from the normal mode to the abnormal one [38-40]). Therefore at small interelectrode distance values the obstructed mode is expressed weakly, what may be observed in Fig. 6. The negative glow does not extend far over the cathode edge limits. When the anode is moving away from the cathode edge by $27 \mathrm{~mm}$, the anode glow appears (in Fig. 5,b it is a thin glowing film near the anode surface), and with the anode moving still further away a positive column is also formed.

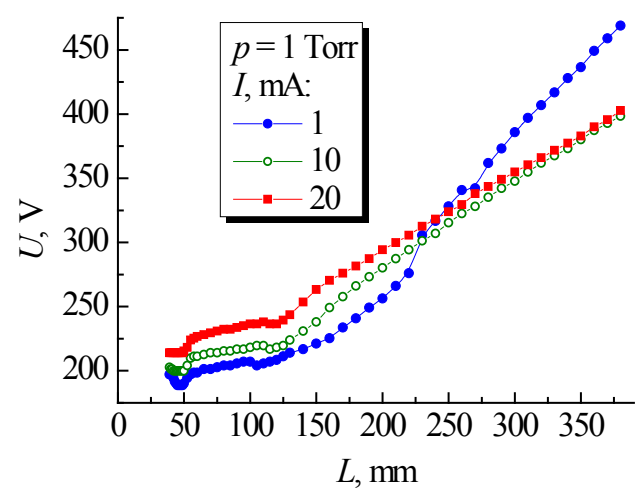

Fig. 6. Voltage across the electrodes against the distance between the flat portion of the hollow cathode and the anode at the argon pressure of 0.1 Torr and the discharge current of $5 \mathrm{~mA}$ (glow mode) and $20 \mathrm{~mA}$ (hollow mode)

As was said above, a linear portion corresponding to the positive column is observed on the voltage dependence on distance when the anode is located sufficiently far from the cathode. One may also observe such linear portions in Fig. 6 for the pressure value of 1 Torr. However, it is clear from the figure that the tilt of linear portions decreases with the discharge current growing. This indicates the decrease of the electric field strength in the positive column [34]. Current increase entails the Joule heating growth of the gas, the concentration $N$ of gas molecules decreases and the reduced electric field $E / N$ grows. As the ionization rate is a steep function of the reduced field, then in order to sustain the balance between the ionization production and loss of charged particles lesser $E / N$ values are required. Therefore the discharge current increase is accompanied by the electric field strength lowering in the positive column.

In the second part of our paper we report our measurements of the emission spectra of the hollow cathode discharge (Fig. 7), when the spectrometer was shifted along the discharge tube axis.

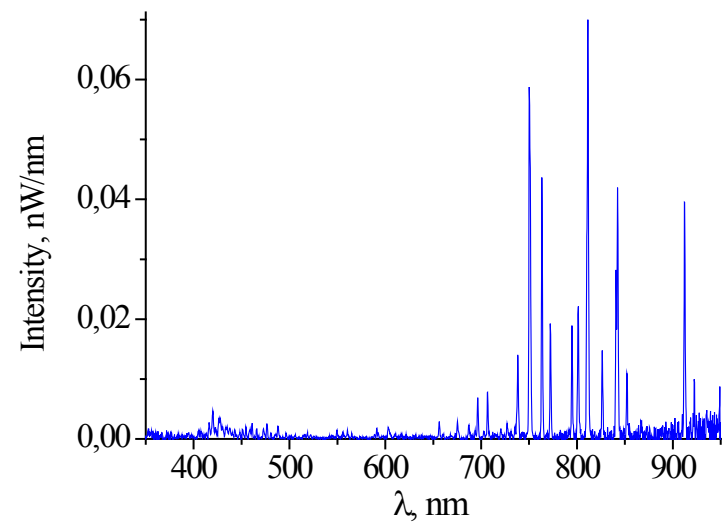

Fig. 7. Emission spectrum of the discharge in the cathode cavity in the hollow mode at the argon pressure of 0.1 Torr, the current of $5 \mathrm{~mA}$

As a result we have obtained the axial intensity profiles of the emission lines of argon atoms and ions for the inter-electrode distance of $100 \mathrm{~mm}$ (maximum distance between the anode and the flat part of the hollow 
cathode). Two groups of lines are well expressed in the emission spectra. The lines corresponding to the transitions from the $3 p^{5} 4 p$ to $3 p^{5} 4$ s levels dominate for wavelength from $667 \mathrm{~nm}$ and above (up to $1148 \mathrm{~nm}$ ). The scheme of these levels is presented, e.g. in paper [41], in total one observes 30 lines for the transition between these levels. The $3 p^{5} 4 p$ set consists of 10 levels in the energy range from 12.91 to $13.48 \mathrm{eV}$, and the $3 \mathrm{p}^{5} 4 \mathrm{~s}$ set consists of two metastable levels $\left(1 \mathrm{~s}_{5}\right.$ and $1 \mathrm{~s}_{3}$ with the energies of 11.55 and $11.72 \mathrm{eV}$, respectively) and two radiative levels $\left(1 \mathrm{~s}_{2}\right.$ and $1 \mathrm{~s}_{4}$, the energies of 11.83 and $11.62 \mathrm{eV})$. The $3 p^{5} 4 \mathrm{p}$ levels are the lowest ones and the transitions from them furnish the lines in the near infrared and visible ranges which our spectrometer can register. The second group of lines is observed in the wavelength range from $600 \mathrm{~nm}$ and lower. This range contains the transitions from higher levels of argon atoms as well as the argon ion lines. It is clear that line intensities in this wavelength range are much lower than those for the transitions from $3 p^{5} 4 p$ to $3 p^{5} 4$ s levels.

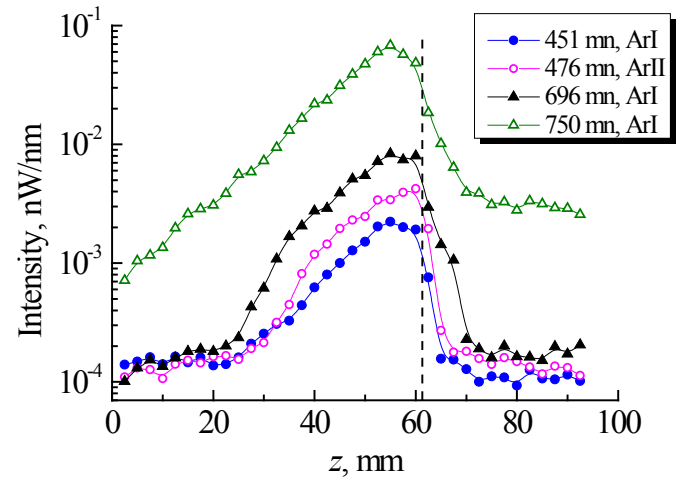

Fig. 8. Discharge photo and axial profiles of emission lines of argon atoms and ions in the high-voltage (glow) mode at the pressure of 0.1 Torr, the current of $5 \mathrm{~mA}$ and the maximum distance between the flat portions of the electrodes of $100 \mathrm{~mm}$

Consider first the high-voltage regime (Fig. 8), which is characterized by the presence of the electron beam leaving the cathode cavity. The same Fig. 8 presents the axial profiles of two lines (750 and $696 \mathrm{~nm}$ ) for the transitions from $3 p^{5} 4 p$ to $3 p^{5} 4 s$ levels, one line $(451 \mathrm{~nm})$ for the transition from a higher level and one line $(476 \mathrm{~nm})$ of the argon ion glow. It is clear that the emission is weak inside the cavity but it grows fast on coming to its edge, approaches a maximum value in the region where the electron beam enters the negative glow. Further, the intensity of the $750 \mathrm{~nm}$ line uniformly decreases according to the exponential law to the anode itself. The intensity of the $451 \mathrm{~nm}$ line decreases with the same rate as the $750 \mathrm{~nm}$ line but at the distance of $20 \mathrm{~mm}$ from the anode its intensity approaches the noise level. The behavior of the $696 \mathrm{~nm}$ line for argon atoms and the $476 \mathrm{~nm}$ one for argon ions differ. First their intensity decreases according to the same exponential law as that for other two lines. But then it lowers abruptly down to the noise level. Such a behavior of emission lines requires additional study.

In the hollow mode (Fig. 9) three amplification regions of line intensity can be observed. Inside the cavity itself the intensities of all lines are high and they remain almost constant in the total space occupied by the plas$\mathrm{ma}$ in the cavity. Note that with the current of $5 \mathrm{~mA}$ in Fig. 9 the discharge occupies only a portion of the cathode cavity, and with a larger current it moves deeper into it.
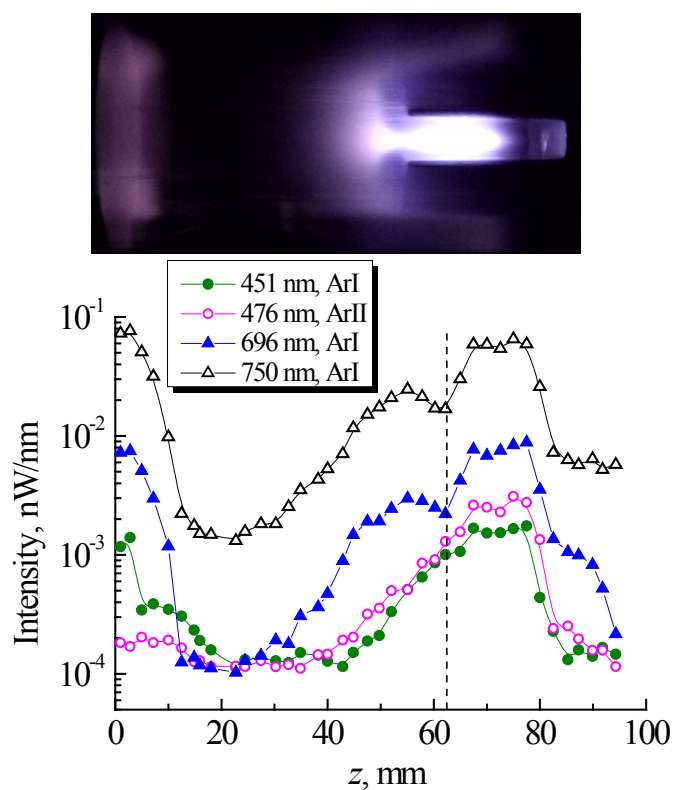

Fig. 9. Discharge photo and axial profiles of emission lines of argon atoms and ions in the hollow mode at the pressure of 0.1 Torr, the current of $5 \mathrm{~mA}$ and the maximum distance between flat portions of the electrodes of $100 \mathrm{~mm}$

The plasma of the negative glow partially leaves the cavity. There, where it is combined with the negative glow enveloping the hollow cathode from outside, the second intensity maximum is observed for the lines corresponding to the transition from $3 p^{5} 4 p$ to $3 p^{5} 4 s$ levels but the intensity of other lines uniformly decreases on moving from the hollow cathode. It indicates that this plasma region contains a small number of electrons with sufficient energy capable to excite high argon levels and still less to ionize an atom during a single collision and to excite the ion produced. A positive column starts to form near the anode. In this region the intensities of the lines for the transitions from the $3 p^{5} 4 p$ level to $3 p^{5} 4$ s one increase by 2 orders of magnitude, for higher levels of the argon atom the increase comprises 1 order of magnitude, and the intensity of argon ion lines does not exceed the noise level for this portion of the spectrum. This is an indication that in the positive column the electron energy is sufficient for the excitation of low levels of argon atoms and for the ionization of atoms with a small rate (which is still sufficient for the sustainment of this part of the discharge).

\section{CONCLUSIONS}

This paper outlines the results of the experimental study of two problems associated with the structure and properties of the glow discharge in argon with a hollow cathode. First, application of a movable flat anode has established how the distance between it and the hollow cathode edge affects the modes of discharge burning. The electron beam is shown to leave the cathode cavity of the high-voltage mode only when the distance values 
between the anode and the hollow cathode exceed $5 \mathrm{~mm}$. At lesser values the anode prevents positive ions from entering the cathode cavity thus leading to the disappearance of the electron beam. Second, employing the optical spectrometer we have measured the emission spectra of argon atoms and ions in the wavelength range from 350 to $1000 \mathrm{~nm}$. Using these spectra we have constructed the axial profiles of a number of emission lines for different gas pressure and discharge current values. The measured spectra are dominated by the lines corresponding to the transitions from $3 p^{5} 4 p$ levels to $3 p^{5} 4 s$ ones. Lines for other transitions in argon atoms and ions possess a small intensity.

\section{REFERENCES}

1. E. Chu et al. High-Current Lanthanum Hexaboride Hollow Cathode for 10-to-50-kW Hall Thrusters // IEEE Trans. Plasma Sci. 2012, v. 40, p. 2133.

2. D. Pedrini, R. Albertoni, et al. Experimental Characterization of a Lanthanum Hexaboride Hollow Cathode for Five-Kilowatt-Class Hall Thrusters // J. Propuls. Power. 2016, v. 32, p. 1557-1561.

3. I.G. Mikellides et al. Wear Mechanisms in Electron Sources for Ion Propulsion, II: Discharge Hollow Cathode // J. Propuls. Power. 2008, v. 24, p. 866.

4. S. Muhl, A. Perez. The use of hollow cathodes in deposition processes: A critical review // Thin Solid Films. 2015, v. 579, p. 174-198.

5. N. Baguera et al. Study of the Ar metastable atom population in a hollow cathode discharge by means of a hybrid model and spectrometric measurements // J. Appl. Phys. 2005, v. 97, p. 123305.

6. A. Bogaerts, M. Grozeva. Axial non-uniformity of longitudinal hollow-cathode discharges for laser applications // Appl. Phys. B. 2002, v. 75, p. 731.

7. A.V. Vizir et al. Further development of a gaseous ion source based on low-pressure hollow cathode glow // Rev. Sci. Instrum. 2000, v. 71, p. 728-730.

8. D. Mihailova et al. A flexible platform for simulations of sputtering hollow cathode discharges for laser applications // J. Phys. D: Appl. Phys. 2008, v. 41, p. 245202.

9. V.A. Lisovskiy, I.A. Bogodielnyi, et al. Axial structure of hollow cathode DC glow discharge in different burning modes // Problems of Atomic Science and Technology. Series "Plasma Electronics and New Methods of Acceleration”.2013, № 4, p. 144-148.

10. V.A. Lisovskiy, R.O. Osmayev, et al. Structure and modes of dc glow discharge in nitrogen with hollow cathode or anode // Problems of Atomic Science and Technologies. Series “Plasma Physics”. 2018, № 6, p. 210-213.

11. Y. Fu, J.P. Verboncoeur, et al. Transition characteristics of low-pressure discharges in a hollow cathode // Phys. Plasmas. 2017, v. 24, p. 083516.

12. V.A. Lisovskiy, D.I. Khilko, R.O. Osmayev, V.D. Yegorenkov. Comparing properties of de discharges in tubes possessing a hollow cathode or anode in an undergraduate laboratory // Eur. J. Phys. 2019, v. 40, doi.org/10.1088/1361-6404/ab1a59

13. V.A. Lisovskiy. Criterion for microwave breakdown of gases // Technical Physics. 1999, v. 44, p. 1282.
14. V.A. Lisovskiy. Determination of electron transport coefficients in argon from ignition curves of $\mathrm{rf}$ and combined low-pressure discharges // Technical Physics Letters. 1998, v. 24, p. 308-310.

15. V. Lisovskiy et al. Double layer onset inside the near-electrode sheath of a RF capacitive discharge in oxygen // Vacuum. 2006, v. 80, p. 458-467.

16. V.A. Lisovskiy, V.D. Yegorenkov. Alpha-gamma transition in RF capacitive discharge in low-pressure oxygen // Vacuum. 2004, v. 74, № 1, p. 19-28.

17. I.A. Soloshenko, V.V. Tsiolko, et al. Features of sterilization using low-pressure DC-discharge hydrogen-peroxide plasma // IEEE Trans. Plasma Sci. 2002, v. 30, p. 1440-1444.

18. V. Lisovskiy, S. Martins, et al. The effect of discharge chamber geometry on the ignition of lowpressure rf capacitive discharges // Physics of Plasmas. 2005, v. 12, № 9, p. 093505.

19. V. Lisovskiy et al. Rf discharge dissociative mode in $\mathrm{NF}_{3}$ and $\mathrm{SiH}_{4} / /$ J. Phys. D: Appl. Phys. 2007, v. 40, № 21, p. 6631-6640.

20. V. Lisovskiy et al. Modes of rf capacitive discharge in low-pressure sulfur hexafluoride // J. Phys. D: Appl. Phys. 2007, v. 40, № 22, p. 6989-6999.

21.W. Krug. Eine neue Glimmentladungserscheinung und ihre Anwendungsmöglichkeit für Braunsche Röhren mit niedrigen Kathodenspannungen // $\mathrm{Na}$ turwissenschaften. 1935, v. 23, p. 355.

22. B.I. Moskalev. Hollow Cathode Discharge. M.: "Energiya", 1969.

23. V.A. Lisovskiy, K.P. Artushenko, et al. Influence of the inter-electrode gap on the cathode sheath characteristics (voltage drop across it and its thickness) // Physics of Plasmas. 2017, v. 24, № 5, p. 053501.

24. V.A. Lisovskiy, K.P. Artushenko, V.D. Yegorenkov. Inter-electrode distance effect on dc discharge characteristics in nitrogen // Problems of Atomic Science and Technology. Series "Plasma Electronics and New Methods of Acceleration”. 2015, № 4, p. 202-205.

25. V.A. Lisovskiy, S.D. Yakovin. Experimental Study of a Low-Pressure Glow Discharge in Air in LargeDiameter Discharge Tubes // Plasma Physics Reports. 2000, v. 26, № 12, p. 1066-1075.

26. V.A. Lisovskiy, E.P. Artushenko, V.D. Yegorenkov. Applicability of Child-Langmuir collision laws for describing a dc cathode sheath in $\mathrm{N}_{2} \mathrm{O} / /$ J. Plasma Physics. 2014, v. 80, p. 319-327.

27. V.A. Lisovskiy, K.P. Artushenko, V.D. Yegorenkov. Child-Langmuir law applicability for a cathode sheath description of glow discharge in hydrogen // Physica Scripta, 2016, v. 91, № 8, p. 085601.

28. V. Lisovskiy et al. Validating the collisiondominated Child-Langmuir law for a dc discharge cathode sheath in an undergraduate laboratory// Eur. J. Phys. 2009, v. 30, № 6, p. 1345.

29. V.A. Lisovskiy et al. The Child-Langmuir collision laws for the cathode sheath of glow discharge in nitrogen // Vacuum. 2014, v. 103, p. 49-56.

30. M.J. Druyvesteyn, F.M. Penning. The mechanism of electrical discharges in gases of low pressure // Rev. Modern Phys. 1940, v. 12, № 2, p. 87-174.

31. V.A. Lisovskiy, V.A. Koval, et al. Validating the Goldstein-Wehner law for the stratified positive col- 
umn of de discharge in an undergraduate laboratory // Eur. J. Phys. 2012, v. 33, p. 1537.

32. V.A. Lisovskiy, E.P. Artushenko, et al. Calculating reduced electric field in diffusion regime of dc discharge positive column // Problems of Atomic Science and Technology. Series "Plasma Physics". 2015, № 1, p. 205-208.

33. V.A. Lisovskiy, E.P. Artushenko, V.D. Yegorenkov. Simple model of reduced electric field in ambipolar regime of dc discharge positive column in hydrogen // J. Plasma Physics. 2015, v. 81, p. 905810312.

34. V.A. Lisovskiy, K.P. Artushenko et al. Reduced electric field in the positive column of the glow discharge in argon // Vacuum. 2015, v. 122, p. 75-81.

35. V.A. Lisovskiy et al. Positive column contraction of the glow discharge in nitrogen // Problems of Atomic Science and Technology. Series "Plasma Physics". 2017, № 1, p. 144-147.

36. G. Cicala et al. Study of positive column of glow discharge in nitrogen // Plasma Sourses Sci. Technol. 2009, v. 18, № 2, p. 025032.
37. V. Lisovskiy, V. Yegorenkov. Ambipolar diffusion in strongly electronegative plasma // Europhysics Letters. 2012, v. 99, № 3, p. 35002.

38. V.A. Lisovskiy et al. Normal mode of dc discharge in argon, hydrogen and oxygen // Problems of Atomic Science and Technology. Series "Plasma Physics”. 2016, № 6, p. 223.

39. V.A. Lisovskiy et al. Normal and abnormal regimes of dc discharge burning in $\mathrm{N}_{2} \mathrm{O}$ // Problems of Atomic Science and Technology. Series "Plasma Physics”. 2013, № 1, p. 210.

40. V. Lisovskiy, V. Yegorenkov, E. Artushenko, et al. Normal regime of the weak-current mode of an $\mathrm{rf}$ capacitive discharge // Plasma Sources Sci. Technol. 2013, v. 22, № 1, p. 015018.

41. J.B. Boffard et al. Optical emission measurements of electron energy distributions in low-pressure argon inductively coupled plasmas // Plasma Sources Sci. Technol. 2010, v. 19, p. 065001.

Article received 10.06.2019

\section{СТРУКТУРА И СВОЙСТВА ТЛЕЮЩЕГО РАЗРЯДА С ПОЛЫМ КАТОДОМ В АРГОНЕ}

\section{В.А. Лисовский, Р.О. Осмаев, Д.И. Хилько, В.Д. Егоренков}

Исследованы режимы горения и структура тлеющего разряда с полым катодом и плоским анодом в аргоне. Показано, что приближение анода к краю полого катода приводит к исчезновению электронного пучка, обычно выходящего из катодной полости в высоковольтном (тлеющем) режиме. Разряд в этом случае горит только на внешней поверхности катодных пластин, образующих полость. На свойства разряда, горящего в полом режиме, перемещение анода не оказывает существенного влияния. Для различных давлений газа и разрядных токов получены осевые профили интенсивности линий излучения атомов и ионов аргона для полого и тлеющего режимов. Показано, что наиболее яркие линии соответствуют переходам с $3 p^{5} 4 p$ на $3 \mathrm{p}^{5} 4 \mathrm{~s}$ уровни. Линии, соответствующие переходам с более высоких уровней, а также линии свечения ионов аргона имеют гораздо более низкую интенсивность.

\section{СТРУКТУРА ТА ВЛАСТИВОСТІ ТЛІЮЧОГО РОЗРЯДУ 3 ПОРОЖНИСТИМ КАТОДОМ В АРГОНІ}

\section{В.О. Лісовський, Р.О. Осмаєв, Д.І. Хілько, В.Д. Сгоренков}

Досліджено режими горіння та структура тліючого розряду з порожнистим катодом і плоским анодом в аргоні. Показано, що наближення анода до краю порожнистого катода призводить до зникнення електронного пучка, що зазвичай виходить з катодної порожнини у високовольтному (тліючому) режимі. Розряд у цьому випадку горить тільки на зовнішній поверхні катодних пластин, що утворюють порожнину. На властивості розряду, що горить у порожнистому режимі, переміщення анода істотно не впливає. Для різних значень тиску газу та розрядного струму отримані осьові профілі інтенсивності ліній випромінювання атомів та іонів аргону для порожнистого та тліючого режимів. Показано, що найбільш яскраві лінії відповідають переходам з $3 p^{5} 4$ н на $3 p^{5} 4 \mathrm{~s}$ рівні. Лінії, що відповідають переходам з більш високих рівнів, а також лінії світіння іонів аргону мають набагато нижчу інтенсивність. 